\title{
Optimisation of Decolourisation Conditions of Crude Shea (Vitellaria paradoxa Gaertner F) Butter: Yellow Type
}

\author{
A. M. Mohagir ${ }^{*}$, C. F. Abi², N. D. Bup ${ }^{3}$, R. Kamga ${ }^{4}$, C. Kapseu ${ }^{4}$ \\ ${ }^{1}$ Faculty of Science and Technologies, University of Sarh, Sarh, Chad \\ ${ }^{2}$ Department of Chemistry, Higher Teachers Training College, University of Yaounde 1, Yaounde, Cameroon \\ ${ }^{3}$ Higher Institute of the Sahel, University of Maroua, Maroua, Cameroon \\ ${ }^{4}$ National Advanced School of Agro-Process Industries, University of Ngaoundéré, Ngaoundéré, Cameroon \\ Email: ${ }^{*}$ amohagir2003@yahoo.fr
}

Received 25 August 2015; accepted 20 October 2015; published 23 October 2015

Copyright (C 2015 by authors and Scientific Research Publishing Inc.

This work is licensed under the Creative Commons Attribution International License (CC BY).

http://creativecommons.org/licenses/by/4.0/

(c) $\underset{\mathrm{EY}}{\mathrm{EP}}$ Open Access

\section{Abstract}

In this study, response surface methodology applying Doehlert experimental design was used to optimise decolourisation parameters of crude yellow shea butter. The decolourisation process was significantly influenced by three independent parameters: contact time, decolourisation temperature and adsorbent dose. The responses of the process were oil loss, acid value, peroxide value and colour index. Contour plots of the decolourisation responses were superimposed and well defined the optimum zone. The optimum decolourisation conditions were found to be: contact time (30 $\mathrm{min})$, decolourisation temperature $\left(80^{\circ} \mathrm{C}-95^{\circ} \mathrm{C}\right)$ and adsorbent dosage $(1-2 \mathrm{mass} \%)$. These conditions gave decolourised shea butter with the following responses; oil loss $(6.2 \% \pm$ $0.2 \%)$, peroxide value $\left(1.7 \pm 0.1 \mathrm{meq} 0_{2} / \mathrm{kg}\right)$, colour $(0.21 \pm 0.05$ Lovibond yellow) and acid value (25.6 $\pm 0.7 \mathrm{mg} \mathrm{KOH} / \mathrm{g})$.

\section{Keywords}

Yellow Shea Butter, Decolourisation, Doehlert Experimental Matrix, RSM, Optimisation

\section{Introduction}

Vegetable oils contain numerous pigments, including chlorophyll, carotenoids, xanthophylls and their derivatives, and these are removed to give the oil a colour that is acceptable to the consumer [1]. Moreover, impurities

${ }^{*}$ Corresponding author.

How to cite this paper: Mohagir, A.M., Abi, C.F., Bup, N.D., Kamga, R. and Kapseu, C. (2015) Optimisation of Decolourisation Conditions of Crude Shea (Vitellaria paradoxa Gaertner F) Butter: Yellow Type. Advances in Chemical Engineering and Science, 5, 505-514. http://dx.doi.org/10.4236/aces.2015.54053 
like free fatty acids, phospholipids and traces of metals were reported [2] [3]. These impurities limit the preservation and uses of the oils. Thus refining of crude oils extends its preservation period and increases its price. Among the most significant stages of any vegetable oil refining process there is decolourisation by adsorption of the pigments on a solid support [4] [5]. Previous studies showed that aluminas, silicas, silico-aluminas and activated clays have the properties to adsorb pigments from vegetable oils [6] [7]. The use of clays for the decolourisation of shea butter has not been well investigated.

Efficiency of decolourisation process depends on many parameters like temperature, contact time, agitation rate, adsorbent dosage, adsorbent particle size, and variety of oils [8] [9]. The evaluation of influence of these parameters on the efficiency of decolourisation process is required for any optimisation procedure. Although there are many works realised on the decolourisation of vegetable oils using different types of adsorbent such as charcoal, clay materials and aluminium and silicon oxides, very few studies had been carried out on the decolourisation of shea butter.

Response surface methodology is based on polynomial surface analysis and it is a collection of mathematical and statistical techniques that are useful for the modeling and analysis of problems in which a response of interest is influenced by several variables [10]. Moreover, response surface methodology could be used to determine the optimum operational conditions of a process [11]. The application of statistical experimental design techniques in adsorption process development can result in improved product yield and its quality [12].

Bike Mbah et al. (2005) [13] studied the decolourisation of shea butter using activated clay and reported that pigments and free fatty acids decreased and peroxides compounds were destroyed with the increase in decolourisation time. Since elimination of free fatty acids, oxidative products, and other impurities of crude oils is the main function of neutralisation process, this work was focused on the decolourisation of shea butter to improve its physicochemical properties. Hence the main objective of this was to optimise the decolourisation parameters of crude black coloured shea butter using tonsil fuller earth.

\section{Material and Methods}

Crude yellow traditionally aqueous extracted shea butter was purchased from Penie village-South of Chad in January 2008. The method of extraction was described by (Adoum, 1996) [14]. Adsorbent was Tonsil fuller earth (240 FE, Olifants, Republic of South Africa), supplied by Cotton Chad Company, Spectrophotometer: Double beam UV-Visible Spectrophotometer of model (SECOMAM, ISO 9001, France), Lovibond Tintometer: Model (F 292, Tintometer Ltd., U.K, with tungsten halogen lamp as source of light).

\subsection{Modelling and Optimisation of Decolourisation Process}

The response surface methodology using the Doehlert experimental matrix was used to investigate the relationship existing between the process responses and the independent parameters and to optimise the process conditions as mentioned early [15] [16]. The selected model was a second degree polynomial equation with interaction as proposed by Doehlert experimental design. The coefficients and the mathematical equations relating the response factors with the independent parameters were generated using the multiple regression techniques installed in Sigmaplot software [17]. Then the mathematical equations were used in the determination of the theoretical zones of optimal response. The validity of models was verified by the coefficient of determination $\mathrm{R}^{2}$ and the absolute average deviation (AAD). The last was calculated following Equation (1).

$$
\mathrm{AAD}=\frac{1}{z} \sum_{i=1}^{Z}\left(\frac{\left|y_{i . \exp }-y_{i . \mathrm{cal}}\right|}{y_{i . \exp }}\right) 100
$$

where $y_{i . e x p}$ and $y_{i . c a l}$ are the experimental and calculated responses respectively, $Z$ is the number of experimental run.

Three independent variables namely contact time $\left(X_{1}: 5\right.$ - $\left.120 \mathrm{~min}\right)$, decolourisation temperature $\left(X_{2}\right.$ : 50 $\left.95^{\circ} \mathrm{C}\right)$, and adsorbent dose $\left(X_{3}: 1-6\right.$ mass \%) were used as main independent parameters based on literature review and preliminary studies. A total of 13 different experiments were enough to study the decolourisation process according to the experimental design. Each experiment was repeated twice and the average values were calculated and used. The experiments are presented in Table 1 in coded values. The response functions $\left(Y_{i}\right)$ measured were oil loss (\%) $\left(Y_{\text {loss }}\right)$, acid value $\left(Y_{\mathrm{Av}}\right)$, peroxide value $\left(Y_{\mathrm{Pv}}\right)$ and colour $\left(Y_{\mathrm{Colour}}\right)$ of shea butter. The 
Table 1. Doehlert experimental design in coded variables $\left(x_{i}\right)$ employed for decolourisation of yellow shea butter.

\begin{tabular}{|c|c|c|c|}
\hline Independent variable & Contact time (5 - 120 min) & Temperature $\left(50^{\circ} \mathrm{C}-95^{\circ} \mathrm{C}\right)$ & Adsorbent dose (1 - 6 mass \%) \\
\hline Exp. No & $x_{1}$ & $x_{2}$ & $x_{3}$ \\
\hline 1 & 0.000 & 0.000 & 0.000 \\
\hline 2 & 1.000 & 0.000 & 0.000 \\
\hline 3 & -1.000 & 0.000 & 0.000 \\
\hline 4 & 0.500 & 0.866 & 0.000 \\
\hline 5 & -0.500 & -0.866 & 0.000 \\
\hline 6 & 0.500 & -0.866 & 0.000 \\
\hline 7 & -0.500 & 0.866 & 0.000 \\
\hline 8 & 0.500 & 0.289 & 0.816 \\
\hline 9 & -0.500 & -0.289 & -0.816 \\
\hline 10 & 0.500 & -0.866 & -0.816 \\
\hline 11 & 0.000 & 0.577 & -0.816 \\
\hline 12 & -0.500 & 0.289 & 0.816 \\
\hline 13 & 0.000 & -0.577 & 0.816 \\
\hline
\end{tabular}

oil loss was expressed as a mass ratio of decolourised oil to that of crude one, while acid and peroxide values were evaluated using the method described in AFNOR (1981) [18]. The responses were related to the coded values $\left(x_{i}\right)$ by the second order polynomial that shown in Equation (2).

$$
Y_{i}=b_{0}+\sum_{i=1}^{k} b_{i} X_{i}+\sum_{i=1}^{k} b_{i i} X_{i}^{2}+\sum_{i=1}^{k-1} \sum_{j=i+1}^{k} b_{i j} X_{i} X_{j}
$$

The coefficients of the polynomial were represented by $b_{0}$ (constant term), $b_{i}$ (linear effects), $b_{i i}$ (quadratic effects) and $b_{i j}$ (interaction effects). $X_{i}$ and $X_{j}$ are the independent variables. The analyses of variance (ANOVA) were generated and the effect and regression coefficients of individual, quadratic and interaction terms were determined. The significances of all terms in the polynomial were judged statistically at a probability $(P)$ of 0.001 , 0.01 and 0.05 . The regression coefficients were then used to make statistical calculation to generate contour map and response surface graphs from the regression models.

\subsection{Procedure of Decolourisation}

The decolourisation apparatus was composed of a $250 \mathrm{ml}$ conical flask equipped with a mechanical agitator of model (Heidolph, RZR1, Germany). The flask was immersed in a thermostated water bath. In each experiment, $30 \mathrm{~g}$ of crude shea butter was heated and maintained at the desired temperature for 15 min before adding the adsorbent, and then the mixture was continuously heated and stirred. The agitation rate used was that just enough to keep the clay dispersed $(150 \mathrm{rpm})$. After decolourisation, the mixture was immediately filtered using Whatman no 1 filter paper on a layer of celite 545 and a vacuum pump of model (960101, Osi-DVD-Bolong, Italy). Each experiment was repeated twice and the results reported are the means of three measurements.

\subsection{Lovibond Colour}

This technique as described by (ISO 15305, 1998) [19], involves matching the colour of light transmitted through a specified depth of oil with the colour of light transmitted from the same light source through a set of coloured glass slides called Lovibond colour glasses. For vegetable oils frequently it requires fixing the yellow numeral in some functional relation to the red or vice versa. The colour of shea butter was measured using Lovibond Tintometer of model (F292, Tintometer Ltd. UK). All the test samples were homogenised to clear liq- 
uids by heating them in an oven set at $50^{\circ} \mathrm{C} \pm 2^{\circ} \mathrm{C}$. In our measurement the red unit was fixed at 10 degree for yellow shea butter and the yellow units were independently varied. The measurements were all carried out using 1 inch glass cells.

\section{Results and Discussions}

\subsection{Modelling of Decolourisation Process}

The data in Table 2 were analysed using multiple regression in Sigmaplot software [17] to fit the proposed polynomial models (Equations (3) - (6)) which explained the influence of independent parameters on the responses of decolourisation process of crude yellow shea butter. These models coefficients are presented in Table 3.

Table 2. Values of experimental results for the decolourisation of yellow shea butter.

\begin{tabular}{cccccccc}
\hline Run & $X_{1}$ & $X_{2}$ & $X_{3}$ & $Y_{\text {loss }}$ & $Y_{\mathrm{Av}}$ & $Y_{\mathrm{Pv}}$ & $Y_{\text {Colour }}$ \\
\hline 1 & 62.50 & 72.50 & 3.50 & $10.4 \pm 0.3$ & $27.6 \pm 0.2$ & $1.55 \pm 0.28$ & $0.30 \pm 0.04$ \\
2 & 120.00 & 72.50 & 3.50 & $8.7 \pm 0.2$ & $26.4 \pm 0.7$ & $2.50 \pm 0.49$ & $0.20 \pm 0.01$ \\
3 & 5.00 & 72.50 & 3.50 & $7.8 \pm 0.2$ & $27.5 \pm 0.5$ & $1.25 \pm 0.35$ & $0.30 \pm 0.03$ \\
4 & 91.25 & 95.00 & 3.50 & $9.8 \pm 0.2$ & $25.0 \pm 0.5$ & $1.60 \pm 0.14$ & $0.20 \pm 0.04$ \\
5 & 33.75 & 50.00 & 3.50 & $12.5 \pm 0.4$ & $26.1 \pm 0.7$ & $1.38 \pm 0.17$ & $0.10 \pm 0.01$ \\
6 & 91.25 & 91.25 & 3.50 & $10.1 \pm 0.5$ & $26.4 \pm 0.4$ & $1.13 \pm 0.18$ & $0.30 \pm 0.07$ \\
7 & 33.75 & 95.00 & 3.50 & $7.3 \pm 0.6$ & $26.1 \pm 0.4$ & $2.03 \pm 0.25$ & $0.20 \pm 0.02$ \\
8 & 91.25 & 80.00 & 6.00 & $12.4 \pm 0.4$ & $25.0 \pm 0.6$ & $1.08 \pm 0.11$ & $0.10 \pm 0.01$ \\
9 & 33.75 & 65.00 & 1.00 & $6.7 \pm 0.2$ & $23.7 \pm 0.1$ & $2.30 \pm 0.35$ & $0.30 \pm 0.06$ \\
10 & 91.25 & 65.00 & 1.00 & $5.3 \pm 0.6$ & $25.2 \pm 0.3$ & $2.00 \pm 0.21$ & $0.30 \pm 0.03$ \\
11 & 62.50 & 87.50 & 1.00 & $7.2 \pm 0.6$ & $24.9 \pm 0.1$ & $2.13 \pm 0.18$ & $0.30 \pm 0.04$ \\
12 & 33.75 & 80.00 & 6.00 & $10.3 \pm 0.5$ & $23.7 \pm 0.4$ & $1.38 \pm 0.17$ & $0.10 \pm 0.02$ \\
13 & 62.50 & 57.50 & 6.00 & $11.9 \pm 0.5$ & $25.1 \pm 0.5$ & $1.25 \pm 0.35$ & $0.10 \pm 0.01$ \\
\hline
\end{tabular}

$X_{1}$ : contact time (min), $X_{2}$ : decolourisation temperature $\left({ }^{\circ} \mathrm{C}\right), X_{3}$ : adsorbent dose (mass \%), $Y_{\text {loss }}$ : Oil loss (\%), $Y_{\mathrm{Av}}$ : acid value (mg KOH/g), $Y_{\mathrm{Pv}}$ : peroxide value (meq $\mathrm{O}_{2} / \mathrm{Kg}$ ), $Y_{\text {Colour }}$ : Lovibond red colour.

Table 3. Regression coefficients, coefficient of determination $\left(\mathrm{R}^{2}\right)$ and absolute average deviation (AAD) for four dependent parameters for decolourisation of yellow shea butter.

\begin{tabular}{ccccc}
\hline Coefficient & Oil loss (\%) & Acid value & Peroxide value & Colour \\
\hline$b_{0}$ & 10.370 & $27.500^{* * *}$ & $1.500^{*}$ & 0.300 \\
$b_{1}$ & 0.361 & 0.000 & 0.156 & 0.00 \\
$b_{2}$ & -1.089 & -0.303 & 0.189 & 0.00 \\
$b_{3}$ & $3.125^{* *}$ & 0.000 & -5.110 & $-0.12^{*}$ \\
$b_{12}$ & 2.870 & -0.808 & 0.000 & -0.12 \\
$b_{13}$ & 1.067 & 0.280 & -0.153 & 0.05 \\
$b_{23}$ & -0.376 & -1.461 & -0.265 & -0.02 \\
$b_{11}$ & -2.135 & -0.500 & 0.375 & -0.05 \\
$b_{22}$ & 0.142 & -2.033 & -0.125 & -0.12 \\
$b_{33}$ & -1.568 & $-3.771^{*}$ & 0.063 & -0.11 \\
$R^{2}$ & 0.96 & 0.87 & 0.60 & 0.85 \\
$\mathrm{AAD}$ & 4.65 & 1.51 & 14.72 & 3.73 \\
\hline
\end{tabular}

$b_{1}=$ contact time, $b_{2}=$ decolourisation temperature, $b_{3}=$ adsorbent dose (mass \%). ${ }^{*}$ Significant at $0.05 ;{ }^{* *}$ Significant at $0.01 ;{ }^{* * *}$ Significant at 0.001. 


$$
\begin{aligned}
Y_{\text {loss }}= & 10.37+0.361 X_{1}-1.089 X_{2}+3.125 X_{3}+2.87 X_{1} X_{2} \\
& +1.067 X_{1} X_{3}-0.376 X_{2} X_{3}-2.135 X_{1}^{2}+0.142 X_{2}^{2}-1.568 X_{3}^{2} \\
Y_{\mathrm{Av}}= & 27.5-3.082 \times 10^{-16} X_{1}-0.303 X_{2}+1.24 \times 10^{-4} X_{3}-0.808 X_{1} X_{2} \\
+ & 0.286 X_{1} X_{3}-1.461 X_{2} X_{3}-0.5 X_{1}^{2}-2.033 X_{2}^{2}-3.771 X_{3}^{2} \\
Y_{\mathrm{Pv}}= & 1.5+0.156 X_{1}+0.198 X_{2}-0.511 X_{3}-9.693 \times 10^{-17} X_{1} X_{2} \\
& -0.153 X_{1} X_{3}-0.265 X_{2} X_{3}+0.375 X_{1}^{2}-0.125 X_{2}^{2}+0.0627 X_{3}^{2} \\
Y_{\text {Colour }}= & 0.3+5.294 \times 10^{-18} X_{1}+2.485 \times 10^{-17} X_{2}-0.123 X_{3}-0.115 X_{1} X_{2} \\
+ & 0.0409 X_{1} X_{3}-0.0235 X_{2} X_{3}-0.05 X_{1}^{2}-0.117 X_{2}^{2}-0.108 X_{3}^{2}
\end{aligned}
$$

From data in Table 3, only adsorbent dose showed significant effect $(P<0.01)$ on the oil loss. it was observed that the oil loss increased marginally as the adsorbent dose increased during the decolourisation of yellow shea butter, while the other two independent variables (contact time, decolourisation temperature) had no significant effect $(P<0.05)$, resulting in a marginal increase in the oil loss with an increase in adsorbent dose. Note that a positive value of $b_{3}(+3.125)$ has a negative effect on the oil loss and vice versa. The increase in oil loss with an increase in adsorbent dose could be attributed to the retention of oil by tonsil fuller earth. It is reported that during bleaching process, fuller earth retains up to 9 of its mass percentage of the oil [20].

As shown in Table 3, the acid value of crude yellow shea butter was high $\left(b_{0}\right)$. This observation was reported in previous investigation [21]. Also it is noticed that only the adsorbent dose had a positive effect on the acid value, as indicated by the negative nature of the quadratic term $\left(b_{33}=-3.77\right)$. The decrease in acid value with an increase in adsorbent dose (mass \%) could be attributed to the adsorption of free fatty acids by adsorbent. Similar observation was reported [13] [22].

The data in Table 3 showed that all the three independent parameters had no significant effect on the peroxide value at $P<0.05$. However, the values of $R^{2}$ and AAD showed that the model of peroxide value had $40 \%$ lack of fit. This might be due to miss use of other independent parameters that could significantly affect the peroxide value during decolourisation process. Meanwhile, the $60 \%$ of the variation explained by the model is discussed. The peroxide value decreased as contact time increased up to $30 \mathrm{~min}$ and then increased gradually throughout the process. The decrease in peroxide value with the increase in contact time could be attributed to the adsorption of hydroperoxides and other oxidants by the adsorbent ( 2.5 mass \%). The adsorption of free fatty acids and destruction of peroxides during bleaching process were also noted [13] [23]. On the other hand, the increase in peroxide value with the increase in decolourisation temperature was probably due to oxidation of shea butter by atmospheric oxygen, since decolourisation process was carried out in an opened environment.

For lovibond colour index, both the linear and quadratic terms of adsorbent dosage showed a positive effect on the colour of yellow shea butter (Table 3). The effects of the interaction of contact time and decolourisation temperature, adsorbent dose and decolourisation temperature on the colour were positive, whereas that of contact time and adsorbent dose was negative. For yellow shea butter, it is observed that at low adsorbent dose (about 3 mass \%) the colour remained constant. However, at high adsorbent dose, the colour decreased considerably to a minimum value. When the contact time was held constant at $65.5 \mathrm{~min}$, the colour increased with the decolourisation temperature until it reached a maximum at about $75^{\circ} \mathrm{C}$ and then decreased. The decrease and increase in colour with the increase in adsorbent dose and temperature was mentioned in previous work [24].

\subsection{Adequacy of the Proposed Models}

The statistical analyses indicated that the proposed models were adequate with satisfactory values of $\mathrm{R}^{2}$ and AAD. The closer the value of $\mathrm{R}^{2}$ to the unity, the better the empirical model fits the actual data. The smaller the value of $\mathrm{R}^{2}$ the less relevant the dependent variables in the model have to explain the behaviour variation [25]. On the other hand, for adequate empirical model, the value of AAD should be as small as possible (0 - 10) [26].

\subsection{Optimisation of the Decolourisation Process}

By analysing the influence of decolourisation conditions on oil loss, colour, acid value and peroxide value of shea butter, all the responses were found to vary substantially with decolourisation temperature and adsorbent 
dose (mass \%) for decolourisation of yellow shea butter. Using the predicted polynomial models (Equations (3)-(6)), contour plots for the independent variables as a function of decolourisation temperature and adsorbent mass percentage were generated and the limits of acceptance were set for each attribute.

The contour plot for oil loss indicated that a high decolourisation temperature and little adsorbent mass \% were necessary to obtain a low oil loss. But, moderate decolourisation temperature $\left(60-70^{\circ} \mathrm{C}\right)$ and high adsorbent dose (mass \%) gave low colour intensity. It is also observed that a high decolourisation temperature gave a high acid value, whereas low decolourisation temperature and a more adsorbent dose (mass \%) produced shea butter with low peroxide value.

\section{Numerical Optimisation}

A numerical optimisation was carried out to identify the overall optimal conditions for oil loss, colour, acid value and peroxide value of shea butter. Mathcad numerical analysis was used to do this part of the work. The criteria applied for numerical optimisation included minimum oil loss $(<7.0 \%)$, Lovibond colour $(<3.0)$, acid value $(<12.0 \%)$ and peroxide value $(<3.0 \%)$.

\subsection{Optimum Conditions}

Using Mathcad software and the model equation 2, the optimum conditions of decolourisation of yellow shea butter were found to be:

1) Oil loss (2.8\%): contact time 15 min, decolourisation temperature $95^{\circ} \mathrm{C}$, adsorbent dosage 1.3 mass \%.

2) Colour index (0.05): contact time $35 \mathrm{~min}$, decolourisation temperature $95^{\circ} \mathrm{C}$, and adsorbent dosage 4.7 mass \%.

3) Acid value (22.6): contact time $20 \mathrm{~min}$, decolourisation temperature $95^{\circ} \mathrm{C}$ and adsorbent dosage 6 mass \%.

4) Peroxide value $(1 \mathrm{meq} / \mathrm{kg})$ : contact time $40 \mathrm{~min}$, decolourisation temperature $55^{\circ} \mathrm{C}$, and adsorbent dosage 6 mass \%. See Figures 1-4.

Since the optimum independent parameters for each response did not fall exactly in the same region, the superimposition of the entire contour plot obtained was done. Figure 5 shows the superimposed contour plots for the responses studied. The criteria considered here were minimum oil loss $(<7.0 \%)$, Lovibond colour, acid value and peroxide value.

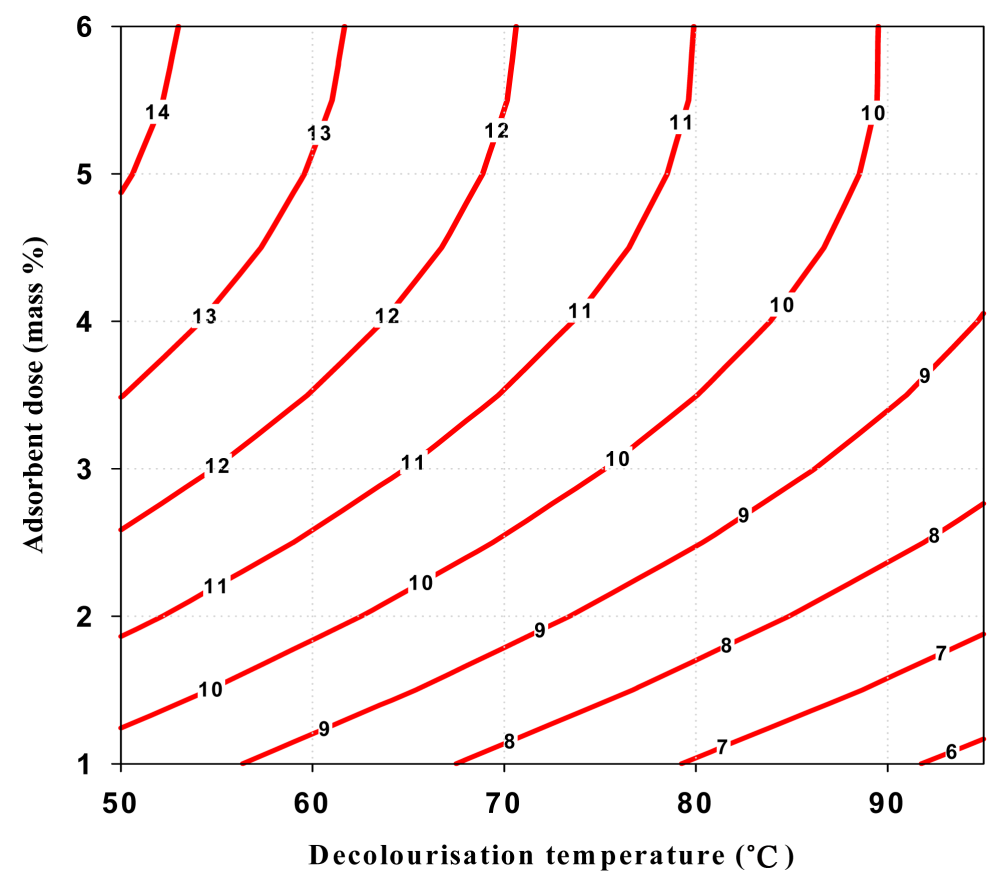

Figure 1. Contour plot of the oil loss as a function of decolourisation temperature and adsorbent dose for yellow shea butter. 


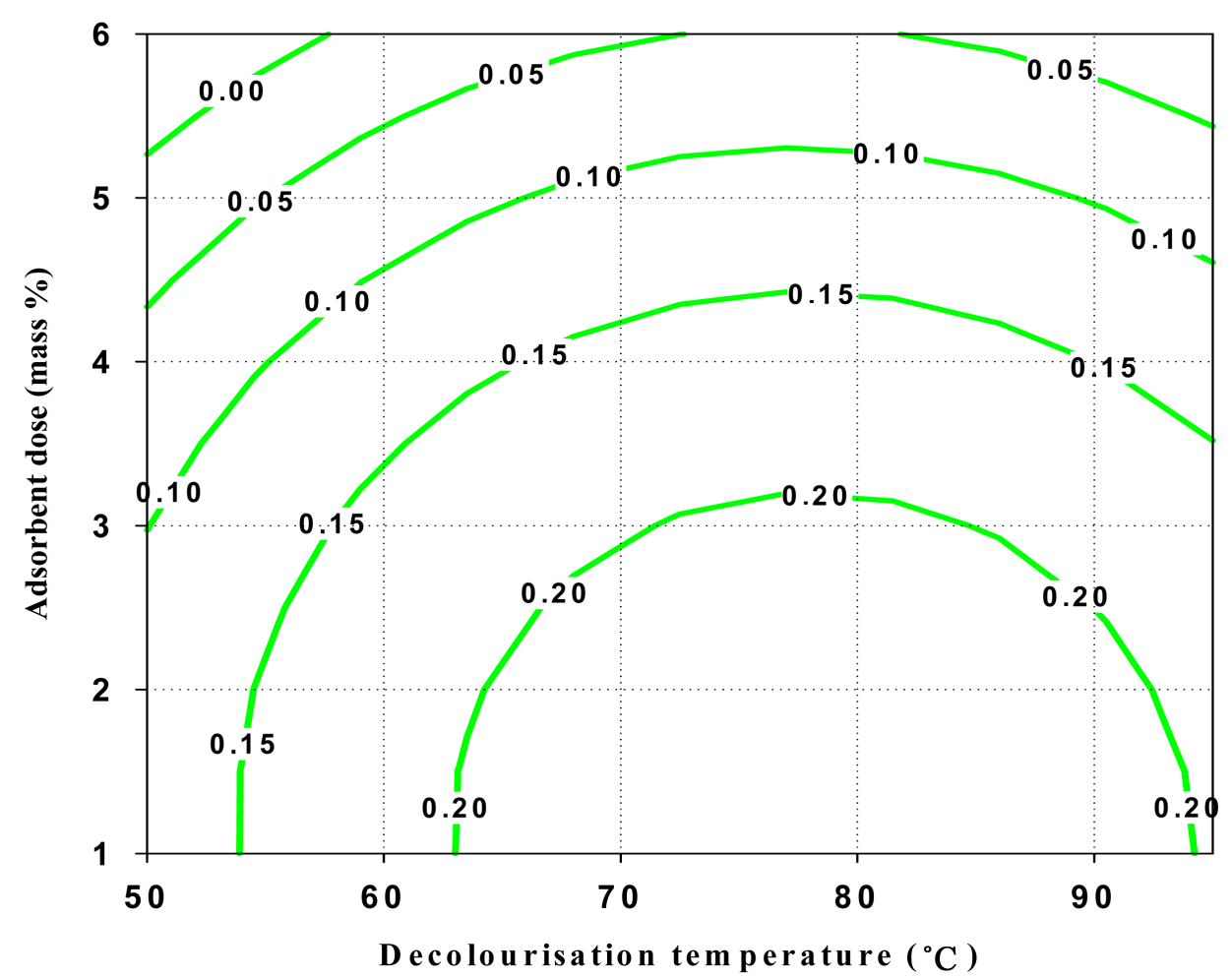

Figure 2. Contour plot of the colour of yellow shea butter as a function of decolourisation temperature and adsorbent dose.

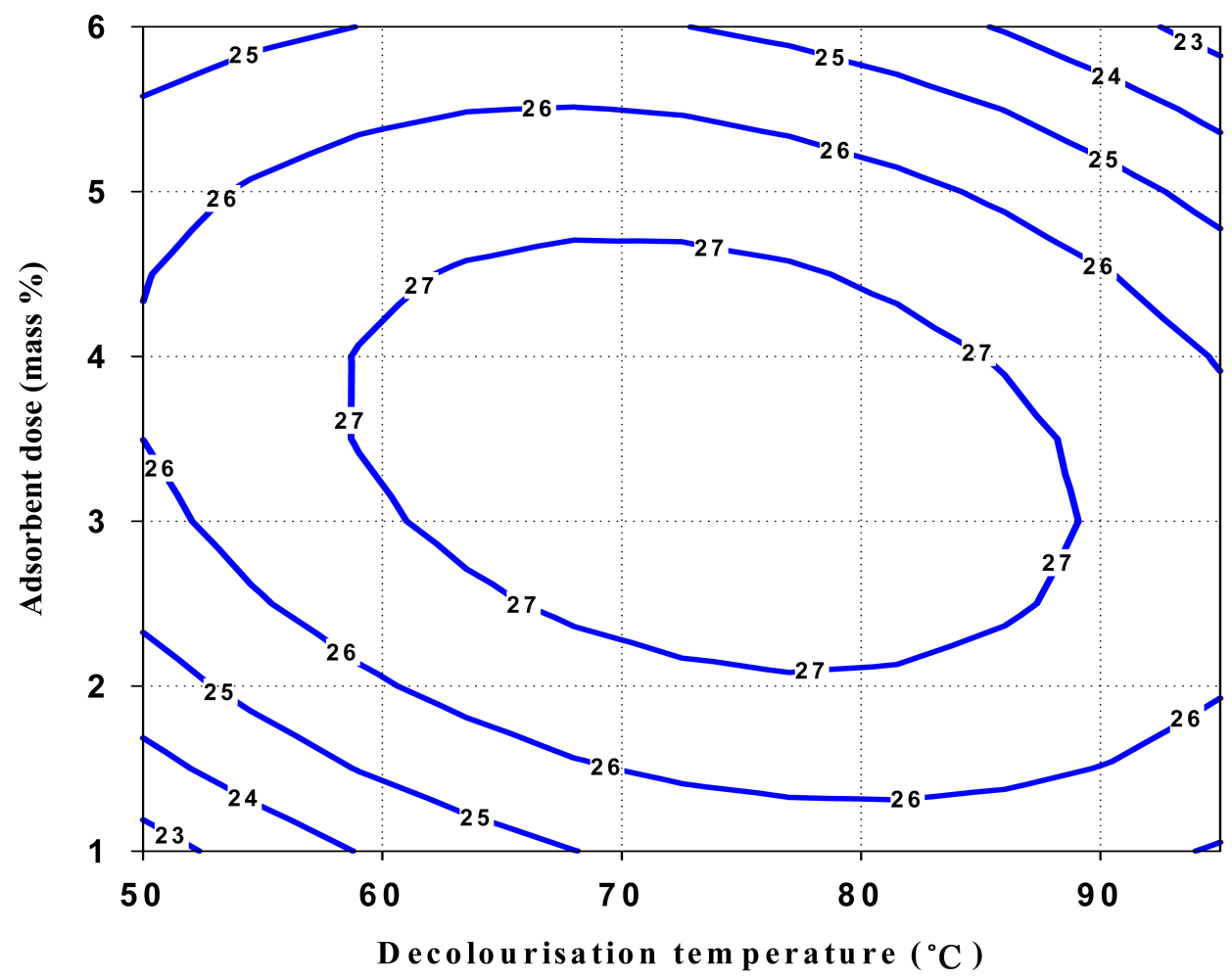

Figure 3. Contour plot of the acid value of yellow shea butter as a function of decolourisation temperature and adsorbent dose. 


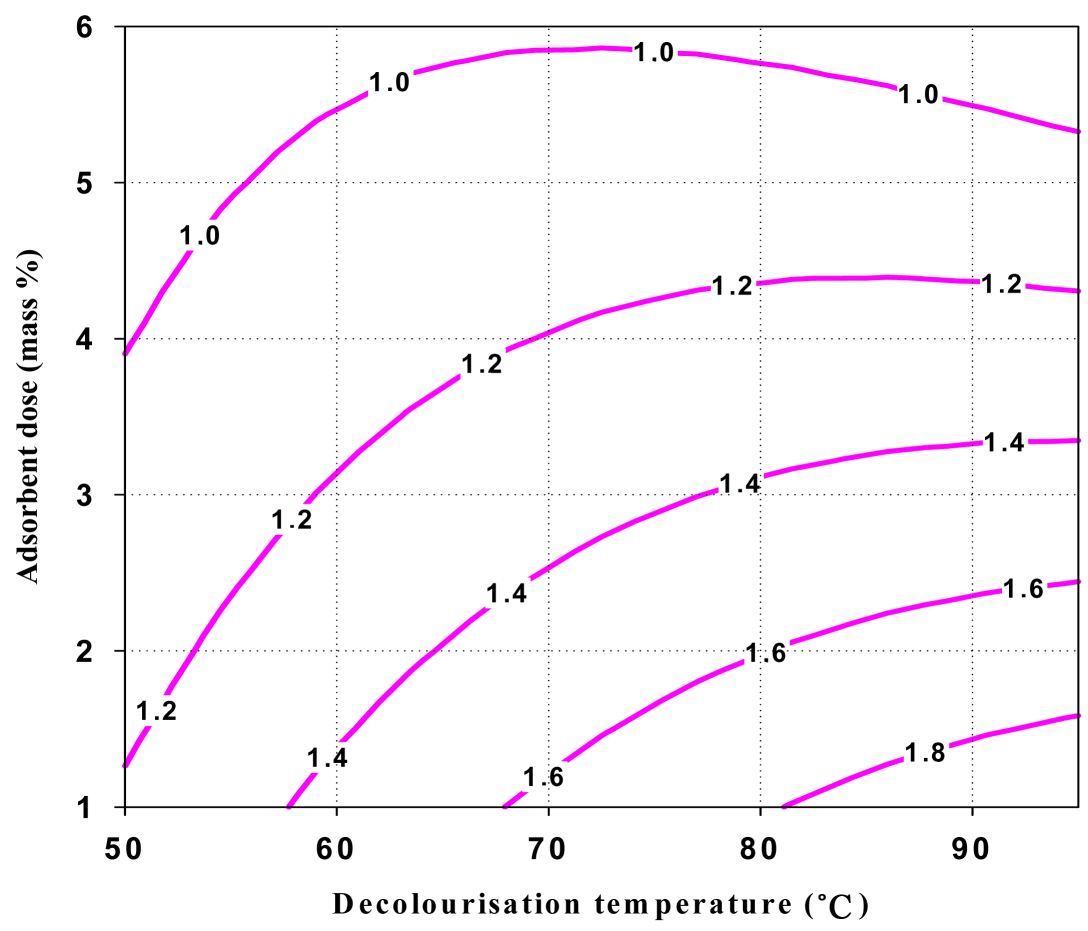

Figure 4. Contour plot of the peroxide value of yellow she a butter as a function of decolourisation temperature and adsorbent dose.

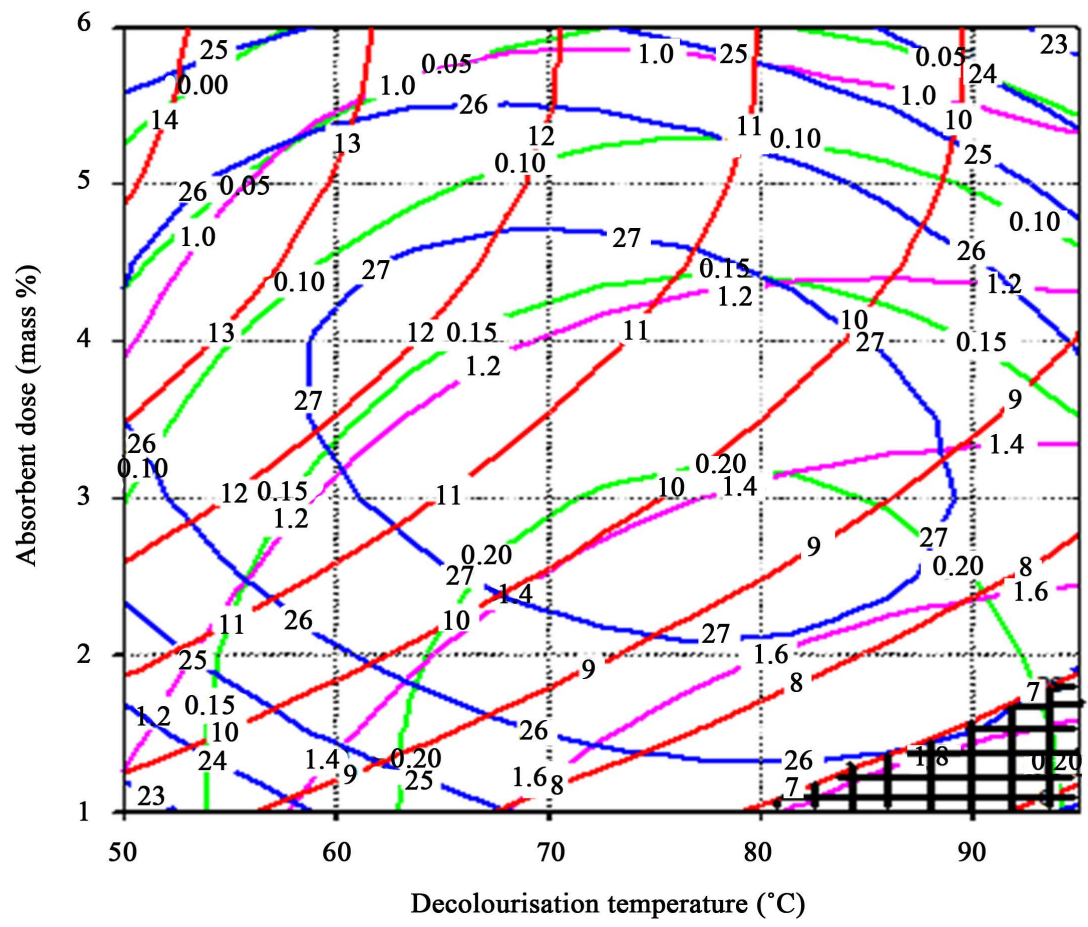

— Oil loss (\%), - Colour, - Acid value, - Peroxide value

Figure 5. Overlaying contour plots for the identification of optimum decolourisation conditions of yellow shea butter. 
The optimum zone (black shaded area) as shown in the Figure 5 depicts $\left(80^{\circ} \mathrm{C}-95^{\circ} \mathrm{C}\right)$ decolourisation temperature and 1 - 2 mass \% adsorbent dose. Moreover, some laboratory tests were carried out in the selected zone and consequently the following parameters were taken as optimum: contact time $30 \mathrm{~min}$, decolourisation temperature $90^{\circ} \mathrm{C} \pm 2^{\circ} \mathrm{C}$ and adsorbent dosage 1.5 mass $\%$. These conditions gave decolourised shea butter with the following responses; oil loss $(6.2 \% \pm 0.2 \%)$, peroxide value $\left(1.7 \pm 0.1\right.$ meq $\left.\mathrm{O}_{2} / \mathrm{kg}\right)$, colour $(0.21 \pm 0.05$ Lovibond yellow) and acid value (25.6 $\pm 0.7 \mathrm{mg} \mathrm{KOH} / \mathrm{g})$.

\section{Conclusion}

Response surface methodology using Doehlert experimental design was successfully applied in the optimisation of decolourisation parameters of crude yellow shea butter. Second order polynomial models with satisfactory validation in terms of coefficient of determination $\left(\mathrm{R}^{2}\right)$ and absolute average deviation (AAD), were generated and described the decolourisation process. The optimum decolourisation conditions were found to be: $30 \mathrm{~min}$ contact time, $72^{\circ} \mathrm{C}-95^{\circ} \mathrm{C}$ decolourisation temperature and $1.5-2.5$ mass \% adsorbent dosage.

\section{Acknowledgments}

This work is supported by the French Government through EGIDE program and University of N'djamena, Chad.

\section{References}

[1] Kaynak, G., Ersoz, M. and Kara, H. (2004) Investigation of the Properties of Oil at the Bleaching Unit of an Oil Refinery. Journal of Colloid and Interface Science, 280, 131-138. http://dx.doi.org/10.1016/j.jcis.2004.07.022

[2] Boki, K., Kubo, M., Wada, T. and Tamura, T. (1992) Bleaching of Alkali-Refined Vegetable Oils with Clay Minerals. Journal of the American Oil Chemists Society, 69, 233-236. http://dx.doi.org/10.1007/bf02635892

[3] Sabah, E., Çinar, M. and Çelik, M.S. (2007) Decolorization of Vegetable Oils: Adsorption Mechanism of $\beta$-Carotene on Acid Activated Sepiolite. Food Chemistry, 100, 1661- 1668. http://dx.doi.org/10.1016/j.foodchem.2005.12.052

[4] Norris, F.A. (1982) Bailey’s Industrial Oil and Fat Products. D. Swem, Ed., 4th Edition, Interscience Publishers, New York, 294-314.

[5] Kamga, R., Kayem, J. and Rouxhet, P. (2001) Adsorption of Gossypol from Cottonseed Oil on the Oxide. Journal of Colloid and Interface, 232, 198-206. http://dx.doi.org/10.1006/jcis.2000.7191

[6] Hüseyin, T. (1998) Bleaching Kinetics of Sunflower Seed Oil. Journal of the American Oil Chemists' Society, 75, 531-533. http://dx.doi.org/10.1007/s11746-998-0260-z

[7] Falaras, P., Lezou, F., Seiragakis, G. and Petrakis, D. (2000) Bleaching Properties of Alumina-Pillared Acid-Activated Montmorillonite. Clays and Clay Minerals, 48, 549-556. http://dx.doi.org/10.1346/CCMN.2000.0480507

[8] Brimberg, U. (1982) Kinetics of Bleaching of Vegetable Oils. Journal of the American Oil Chemists' Society, 59, 74-78. http://dx.doi.org/10.1007/BF02678716

[9] Sabah, E. and Çelik, M.S. (2005) Sepiolite: An Effective Bleaching Adsorbent for the Physical Refining of Degummed Rapeseed Oil. Journal of the American Oil Chemists' Society, 82, 911-916. http://dx.doi.org/10.1007/s11746-005-1164-4

[10] Mathieu, D. and Phan-Tan-Luu, R. (1995) Approche méthodologique des surfaces de réponse. In: Plan d'expériences Applications à l'entreprise, Editions Technip, Paris, 211-278.

[11] Kumar, A., Prasad, B. and Mishra, I.M. (2007) Process Parametric Study of Ethene Carboxydic Acid Removal onto Power Activated Carbon Using Box-Behnken Design. Chemical Engineering \& Technology, 30, 932-937. http://dx.doi.org/10.1002/ceat.200700084

[12] Annadurai, G., Juang, R.S. and Lee, D.J. (2002) Factorial Design Analysis of Adsorption of Activated Carbon on Activated Carbon Incorporated with Calcium Aginate. Advances in Environmental Research, 6, 191-198. http://dx.doi.org/10.1016/S1093-0191(01)00050-8

[13] Bike Mbah, J.B., Kamga, R., Nguetnkam, J.P. and Fanni J. (2005) Adsorption of Pigments and Free Fatty Acids from Shea Butter on Activated Cameroonian Clays. European Journal of Lipid Science and Technology, 107, 387-394. http://dx.doi.org/10.1002/ejlt.200501149

[14] Adoum, D. (1996) Technique artisanale d'extraction du beurre de karité à Moyen Chari sud du Tchad. Actes du séminaire atelier oléagineux et petites technologies II. 23-27 Septembre APICA, ENSAI, Editeur: André Eberrad, 92-96.

[15] Mohagir, A.M., Kamga, R., Kapseu, C. and Abi, C.F. (2009) Optimization of Some Pre-Treatments Involved in the Press Extraction of Shea (Vitellaria paradoxa Gaertner F.) Butter. Asian Journal of Applied Sciences, 2, 372-384. 
http://dx.doi.org/10.3923/ajaps.2009.372.384

[16] Mohagir, A.M., Kamga, R. and Kapseu, C. (2011) Influence of Operating Conditions on the Extraction of Shea (Vitellaria Paradoxa Gaertner F.) Butter. In: Ardil, C., Ed., Proceedings of International Conference on Applied Chemistry, WASET (World Academy of Science, Engineering and Technology), Paris, 1641-1654.

[17] SigmaPlot ${ }^{\circledR}$ for windows, Version 9.01, Systatsoftware, Inc. USA, 2004.

[18] AFNOR (Association Française pour la Normalisation) (1981) Recueil des normes françaises, Corps gras, graines oléagineuses, produits dérivés. $2^{\text {ième }}$ édition, Paris, 438 p.

[19] ISO 15305 (1998) Animal and Vegetable Fats and Oils Determination of Lovibond Colour, Chinese National Standard GB 552585, 1985, Inspection of Vegetable Oils: Methods for Identification of Transparency, Colour, Odour and Taste.

[20] Chritidis, G. and Kosiari, S. (2003) Decolorization of Vegetable Oils: A Study of the Mechanism of Adsorption of $\beta$-Carotene by Acid-Activated Bentonite from Cyprus Clay. Clays and Clay Minerals, 51, 327-333. http://dx.doi.org/10.1346/CCMN.2003.0510309

[21] Mohagir, A.M. (2003) Aqueous Extraction of Butter from Kernels of Shea Tree (Butyrospermum parkii G. Don Kotschy). M. Sc. Eng. Thesis, ENSAI (École Nationale Supérieure des Sciences Agro Industrielles), University of Ngaoundéré, Ngaoundéré, Cameroon, 87 p.

[22] Kheok, S. and Lim, E. (1982) Mechanism of Palm Oil Bleaching by Montmorillonite Clay Activated at Various Acid Concentrations. Journal of the American Oil Chemists Society, 59, 129-131. http://dx.doi.org/10.1007/BF02662259

[23] Nde-Aga, B., Kamga, R. and Nguetnkam, J.P. (2007) Adsorption of Palm Oil Carotene and Free Fatty Acid onto Acid Activated Cameroonian Clays. Journal of Applied Sciences, 7, 2462-2467. http://dx.doi.org/10.3923/jas.2007.2462.2467

[24] Mohagir, A.M., Ahmat-charfadine, M., Bup, N.D., Kamga, R. and Kapseu, C. (2015) Influence of Decolourisation Condition on the Physicochemical Properties of Shea (Vitellaria paradoxa Gaertner F) Butter. Research Journal of Applied Sciences, Engineering and Technology, 9, 736-744.

[25] Mendenhall, W. (1975) Introduction to Probability and Statistics. 4th Edition, North Settuate, M. A., Duxbury Pres, USA, 273 p.

[26] Fermeglia, M., Paricl, S. and Longo, G. (2003) Molecular Modelling and Process Simulation: Real Possibilities and Challenges. Chemical and Biochemical Engineering Quarterly, 17, 69-79.

\section{Nomenclatures}

$\begin{array}{ll}\mathbf{R}^{2} & \text { Coefficient of determination } \\ \mathbf{A A D} & \text { Absolute Average Deviation } \\ \mathbf{Y}_{\mathbf{i}} & \text { response function } \\ \mathbf{Y}_{\mathbf{A v}} & \text { acid value (mg KOH/g oil) } \\ \mathbf{Y}_{\mathbf{P v}} & \text { peroxide value (meq } \mathrm{O}_{2} / \mathrm{kg} \text { oil) } \\ \mathbf{Y}_{\text {Colour }} & \text { lovibond colour index } \\ \mathbf{y}_{\text {i.exp }} & \text { experimental response } \\ \mathbf{y}_{\mathbf{i} . \mathbf{c} \text { l }} & \text { calculated response } \\ \mathbf{y} & \text { yield (g/g) } \\ \mathbf{t} & \text { time (min) } \\ \mathbf{a} ; \mathbf{b} & \text { constants. } \\ \mathbf{Z} & \text { number of experimental run } \\ \mathbf{X}_{\mathbf{i}} ; \mathbf{X}_{\mathbf{j}} & \text { independent variables } \\ \mathbf{x}_{\mathbf{i}} & \text { coded value } \\ \mathbf{X}_{\mathbf{1}} & \text { contact time (min) } \\ \mathbf{X}_{\mathbf{2}} & \text { decolourisation temperature }\left({ }^{\circ} \mathrm{C}\right) \\ \mathbf{X}_{\mathbf{3}} & \text { adsorbent dose (mass } \%) \\ \mathbf{b}_{\mathbf{0}} & \text { constant term } \\ \mathbf{b}_{\mathbf{i}} & \text { inear effect } \\ \mathbf{b}_{\mathbf{i i}} & \text { quadratic effect } \\ \mathbf{b}_{\mathbf{i j}} & \text { interaction effect } \\ \mathbf{P} & \text { probability (0.001, 0.01 and 0.05) }\end{array}$

